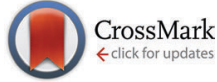

Cite this: Phys. Chem. Chem. Phys., 2016, 18, 15838

Received 25th April 2016, Accepted 19th May 2016

DOI: $10.1039 / \mathrm{c} 6 \mathrm{cp} 02762 \mathrm{~h}$

www.rsc.org/pccp

\section{Reactive force field development for magnesium chloride hydrates and its application for seasonal heat storage $\dagger$}

\author{
Amar Deep Pathak, ${ }^{\text {a }}$ Silvia Nedea, ${ }^{a}$ Adri C. T. van Duin, ${ }^{b}$ Herbert Zondag, ${ }^{a}$ \\ Camilo Rindt ${ }^{\mathrm{a}}$ and David Smeulders ${ }^{\mathrm{a}}$
}

\begin{abstract}
$\mathrm{MgCl}_{2}$ hydrates are considered as high-potential candidates for seasonal heat storage materials. These materials have high storage capacity and fast dehydration kinetics. However, as a side reaction to dehydration, hydrolysis may occur. Hydrolysis is an irreversible reaction, which produces $\mathrm{HCl}$ gas thus affecting the durability of heat storage systems. In this study, we present the parameterization of a reactive force field (ReaxFF) for $\mathrm{MgCl}_{2}$ hydrates to study the dehydration and hydrolysis kinetics of $\mathrm{MgCl}_{2} \cdot \mathrm{H}_{2} \mathrm{O}$ and $\mathrm{MgCl}_{2} \cdot 2 \mathrm{H}_{2} \mathrm{O}$. The ReaxFF parameters have been derived by training against quantum mechanics data obtained from Density Functional Theory (DFT) calculations consisting of bond dissociation curves, angle bending curves, reaction enthalpies, and equation of state. A single-parameter search algorithm in combination with a Metropolis Monte Carlo algorithm is successfully used for this ReaxFF parameterization. The newly developed force field is validated by examining the elastic properties of $\mathrm{MgCl}_{2}$ hydrates and the proton transfer reaction barrier, which is important for the hydrolysis reaction. The bulk moduli of $\mathrm{MgCl}_{2} \cdot \mathrm{H}_{2} \mathrm{O}$ and $\mathrm{MgCl}_{2} \cdot 2 \mathrm{H}_{2} \mathrm{O}$ obtained from ReaxFF are in close agreement with the bulk moduli obtained from DFT. A barrier of $20.24 \mathrm{kcal} \mathrm{mol}^{-1}$ for the proton transfer in $\mathrm{MgCl}_{2} \cdot 2 \mathrm{H}_{2} \mathrm{O}$ is obtained, which is in good agreement with the barrier $\left(19.55 \mathrm{kcal} \mathrm{mol}^{-1}\right.$ ) obtained from DFT. Molecular dynamics simulations using the newly developed ReaxFF on 2D-periodic slabs of $\mathrm{MgCl}_{2} \cdot \mathrm{H}_{2} \mathrm{O}$ and $\mathrm{MgCl}_{2} \cdot 2 \mathrm{H}_{2} \mathrm{O}$ show that the dehydration rate increases more rapidly with temperature in $\mathrm{MgCl}_{2} \cdot \mathrm{H}_{2} \mathrm{O}$ than in $\mathrm{MgCl}_{2} \cdot 2 \mathrm{H}_{2} \mathrm{O}$, in the temperature range 300-500 K. The onset temperature of $\mathrm{HCl}$ formation, a crucial design parameter in seasonal heat storage systems, is observed at $340 \mathrm{~K} \mathrm{for} \mathrm{MgCl}_{2} \cdot \mathrm{H}_{2} \mathrm{O}$, which is in agreement with experiments. The $\mathrm{HCl}$ formation is not observed for $\mathrm{MgCl}_{2} \cdot 2 \mathrm{H}_{2} \mathrm{O}$. The diffusion coefficient of $\mathrm{H}_{2} \mathrm{O}$ through $\mathrm{MgCl}_{2} \cdot \mathrm{H}_{2} \mathrm{O}$ is lower than through $\mathrm{MgCl}_{2} \cdot 2 \mathrm{H}_{2} \mathrm{O}$, and can become a rate-limiting step. The diffusion coefficient increases with temperature and follows the Arrhenius law both for $\mathrm{MgCl}_{2} \cdot \mathrm{H}_{2} \mathrm{O}$ and $\mathrm{MgCl}_{2} \cdot 2 \mathrm{H}_{2} \mathrm{O}$. These results indicate the validity of the ReaxFF approach for studying $\mathrm{MgCl}_{2}$ hydrates and provide important atomistic-scale insight of reaction kinetics and $\mathrm{H}_{2} \mathrm{O}$ transport in these materials.
\end{abstract}

\section{Introduction}

Thermal energy storage is necessary for the successful implementation of solar thermal energy. ${ }^{1}$ Solar thermal energy can be stored in three forms: sensible, latent, and thermochemical. ${ }^{2}$ Thermal storage is a proven concept but it is volume restricted. The energy storage density is higher in thermochemical form than in sensible or latent form. Therefore thermochemical materials (TCMs) may offer a compact seasonal heat storage solution. ${ }^{3}$

\footnotetext{
${ }^{a}$ Energy Technology, P.O. Box 513, 5600 MB Eindhoven, The Netherlands. E-mail: a.d.pathak@tue.nl

${ }^{b}$ Department of Mechanical and Nuclear Engineering, Pennsylvania State University, 240 Research East Building, University Park, PA 16802, USA

$\dagger$ Electronic supplementary information (ESI) available. See DOI: 10.1039/c6cp02762h
}

Salt hydrates are one class of TCMs. ${ }^{1}$ These materials convert thermal energy (physical form of energy) into chemical form by decomposing into lower hydrate form or anhydrous form (charging cycle). Anhydrous and lower hydrates recombine with water vapor (present in moisture) to form hydrates again, thereby releasing energy (discharging cycle). The operating principle of TCM can be expressed with the following reaction:

$$
\text { Salt } m \mathrm{H}_{2} \mathrm{O}+\text { Heat } \leftrightarrow \text { Salt } \cdot(m-n) \mathrm{H}_{2} \mathrm{O}+n \mathrm{H}_{2} \mathrm{O} .
$$

In addition to higher energy storage capacity, TCMs can store thermal energy with almost no heat loss, even for longer periods, making TCM a unique seasonal heat storage material. ${ }^{4,5}$ Selection of an appropriate salt hydrate is the key aspect in designing a thermochemical heat storage system. ${ }^{6}$ Halide based salt hydrates $\left(\mathrm{CaX}_{2} \cdot 6 \mathrm{H}_{2} \mathrm{O}, \mathrm{MgX} \cdot 6 \mathrm{H}_{2} \mathrm{O}\right.$, and $\mathrm{SrX}_{2} \cdot 6 \mathrm{H}_{2} \mathrm{O}$, 
$\mathrm{X}=\mathrm{Cl} / \mathrm{Br})$, sulphate based salt hydrates $\left(\mathrm{LiSO}_{4} \cdot \mathrm{H}_{2} \mathrm{O}, \mathrm{MgSO}_{4} \cdot 7 \mathrm{H}_{2} \mathrm{O}\right)$, and nitrate based salt hydrates $\left(\mathrm{LiNO}_{3} \cdot 3 \mathrm{H}_{2} \mathrm{O}, \mathrm{Zn}\left(\mathrm{NO}_{3}\right)_{2} \cdot 3 \mathrm{H}_{2} \mathrm{O}\right)$ are the major class of promising reversible TCMs. ${ }^{6}$ These hydrates have theoretical crystal storage capacities between 2-3 $\mathrm{GJ} \mathrm{m}^{-3}$.

Magnesium chloride hydrates $\left(\mathrm{MgCl}_{2} \cdot n \mathrm{H}_{2} \mathrm{O}, n=0,1,2,4\right.$, and 6) have been investigated extensively as an appropriate candidates for solar thermal storage. ${ }^{7-13} \mathrm{MgCl}_{2} \cdot 6 \mathrm{H}_{2} \mathrm{O}$ (Bischofite) has been successfully tested for 1000 cycles for application in solar based cooking. ${ }^{11}$ Thermal dehydration of Bischofite is an important process in production of pure $\mathrm{Mg}, \mathrm{Mg}$ alloys, $\mathrm{MgO}$, and in heat storage applications. ${ }^{14-17}$ The dehydration kinetics for $\mathrm{MgCl}_{2}$ hydrates is faster than for other materials like $\mathrm{MgSO}_{4}$ hydrates, ${ }^{8,18}$ but a problem with this material is the presence of the hydrolysis along with the dehydration. Hydrolysis is an irreversible side reaction in the dehydration process, which produces $\mathrm{HCl}$ gas and affects the durability of the heat storage system. It was experimentally observed that the hydrolysis reaction could be avoided by use of external $\mathrm{HCl}$ pressure ${ }^{14}$ or by adding other halides. ${ }^{19}$ However, there is no fundamental understanding of the conditions for the hydrolysis.

Next to the dehydration, the $\mathrm{HCl}$ production is also a key aspect in designing the $\mathrm{MgCl}_{2}$ based heat storage system. Experimentally, thermal dehydration and hydrolysis of $\mathrm{MgCl}_{2}$ hydrates have been studied by thermogravimetric analysis (TGA), ${ }^{17}$ derivative thermogravimetry (DTG), ${ }^{20}$ TGA/Differential scanning calorimetry (DSC) ${ }^{10}$ and thermochemical analysis. ${ }^{14}$ Galwey et $a .^{21}$ has experimentally observed the hydrolysis reaction in $\mathrm{MgCl}_{2} \cdot 2 \mathrm{H}_{2} \mathrm{O}$ in the temperature range of $623-703 \mathrm{~K}^{21}$ Kirsh et al. $^{20}$ has not observed hydrolysis below $473 \mathrm{~K}$ for $\mathrm{MgCl}_{2}$ hydrates, but found $43.8 \%$ of chlorine released as $\mathrm{HCl}$ at $673 \mathrm{~K}$. However, Huang et al. ${ }^{17}$ has reported the onset temperature of $\mathrm{HCl}$ formation at $440 \mathrm{~K}$ in $\mathrm{MgCl}_{2} \cdot 2 \mathrm{H}_{2} \mathrm{O}$. Kipouros et al. ${ }^{14}$ has reported hydrolysis at $417 \mathrm{~K}$ for $\mathrm{MgCl}_{2} \cdot 2 \mathrm{H}_{2} \mathrm{O}$ and at $413 \mathrm{~K}$ for $\mathrm{MgCl}_{2} \cdot \mathrm{H}_{2} \mathrm{O}$ for an equilibrium $\mathrm{HCl}$ pressure of $5 \times 10^{-3} \mathrm{~atm}$. The onset temperature of $\mathrm{HCl}$ formation is thus ambiguous from experiments. There is no theoretical study to determine the hydrolysis kinetics and the onset temperature of $\mathrm{HCl}$ formation.

Atomic and molecular level simulations turned to be useful tools to gain insight in the hydrolysis coupled dehydration reactions. Weck et al. ${ }^{12}$ has computed thermal properties from thermodynamical calculations of $\mathrm{MgCl}_{2} \cdot n \mathrm{H}_{2} \mathrm{O}$ using Density Function Theory (DFT) under harmonic assumption. Wang et al. ${ }^{16}$ has considered $\mathrm{MgCl}_{2} \cdot \mathrm{H}_{2} \mathrm{O}$ to be the potential candidate for hydrolysis and proposed a reaction path for thermolysis of $\mathrm{MgCl}_{2} \cdot \mathrm{H}_{2} \mathrm{O}$ from DFT calculations. Smeets et al. ${ }^{8}$ has obtained the safety limit of hydrolysis reactions for all hydrates of $\mathrm{MgCl}_{2}$ from DFT calculations using equilibrium thermodynamic principles under the ideal poly-atomic gas assumption. The atomic scale calculations can simulate systems upto a system size of 100-1000 atoms and a time scale upto 200 picosecond over a week of high performance computing. ${ }^{22}$ To the best of our knowledge, no kinetic study was done on molecular level to investigate the hydrolysis and dehydration reactions of $\mathrm{MgCl}_{2} \cdot \mathrm{H}_{2} \mathrm{O}$ and $\mathrm{MgCl}_{2} \cdot 2 \mathrm{H}_{2} \mathrm{O}$ from first principle atomic level calculations, integrating the quantum level results to molecular level modeling under reactive force field (ReaxFF) formalism.
For an efficient TCM storage cycle, heat and mass transfer in the storage volume are essential. ${ }^{2}$ Experimentally it has been observed that water transport through the solid $\mathrm{MgCl}_{2}$ hydrate affects the dehydration rate and may become the rate limiting step under specific reaction conditions. ${ }^{23}$ To understand the complex reaction (hydration and dehydration) coupled with water transport, it is desirable to investigate the diffusive transport of water molecules, which are formed by the dehydration reaction. These water molecules have to diffuse to the surface of the solid salt hydrate. The diffusion path may vary from several atomic layers up to a few micrometer. ${ }^{24}$ The water transport through the solid salt hydrate, the temperature, the diffusion path length, the external $\mathrm{H}_{2} \mathrm{O}$ pressure and the crystal defects influence considerably the dehydration rate. ${ }^{25}$ To study the effect of these aspects on the complex dehydration reaction on molecular level, a force field is required that is able to capture both the chemical reactivity and the mass transport of $\mathrm{H}_{2} \mathrm{O}$ in $\mathrm{MgCl}_{2} \cdot \mathrm{H}_{2} \mathrm{O}$ and $\mathrm{MgCl}_{2} \cdot 2 \mathrm{H}_{2} \mathrm{O}$ crystals.

Chemical reactivity has been incorporated using bond order dependent ReaxFF. ${ }^{26,27}$ According to previous studies, ${ }^{28,29}$ a training set needs to be developed from quantum level DFT calculations consisting of the bond dissociation energy curves of $\mathrm{Mg}-\mathrm{Cl}$ and $\mathrm{Mg}-\mathrm{O}$ bonds, the angle bending energy curves of $\mathrm{Cl}-\mathrm{Mg}-\mathrm{Cl}, \mathrm{O}-\mathrm{Mg}-\mathrm{O}$, and $\mathrm{O}-\mathrm{Mg}-\mathrm{Cl}$ angles in gaseous hydrates, the reaction enthalpies of dehydration and hydrolysis reaction, and the condensed phase equation of state (EOS) of $\mathrm{MgCl}_{2}$, $\mathrm{MgCl}_{2} \cdot \mathrm{H}_{2} \mathrm{O}$ and $\mathrm{MgCl}_{2} \cdot 2 \mathrm{H}_{2} \mathrm{O} \cdot{ }^{27,30,31}$ To our knowledge, no DFT studies exist presenting this information of the $\mathrm{MgCl}_{2}$ hydrates. For this purpose, in this paper we obtained various molecular structures of $\mathrm{MgCl}_{2}$ hydrates, reaction enthalpies, bond dissociation energies, angle bending energies, and EOS from DFT. With this extended information, we parameterize a new force field for $\mathrm{MgCl}_{2}$ hydrates. Both a single-parameter search algorithm ${ }^{32}$ and a Metropolis Monte Carlo (MMC) algorithm ${ }^{33}$ are used to optimize the newly developed ReaxFF for investigated $\mathrm{MgCl}_{2}$ hydrates.

In the present study, we parameterize the ReaxFF to model the dehydration kinetics of $\mathrm{MgCl}_{2} \cdot \mathrm{H}_{2} \mathrm{O}$ and $\mathrm{MgCl}_{2} \cdot 2 \mathrm{H}_{2} \mathrm{O}$, as these hydrates are prone to hydrolysis reactions. Proton transfer is an important step in the hydrolysis reaction. The energy barrier for proton transfer in $\mathrm{MgCl}_{2} \cdot 2 \mathrm{H}_{2} \mathrm{O}$ is obtained from the ReaxFF simulations and validated against results from DFT. The extent of the reaction depends on the temperature of the solid and the vapor transport inside the solid. The new ReaxFF is used to study the effect of temperature on the dehydration in the temperature range of 300-500 K. This temperature range is the typical operating range of TCM based heat storage systems. The onset temperature of $\mathrm{HCl}$ formation is investigated in the same temperature range. The dependence of the diffusion coefficient (DC) on temperature is analyzed using the Green-Kubo (GK) method.

\section{Computational methods}

\subsection{Quantum mechanics calculations}

To accurately predict the dehydration and hydrolysis reaction in the condensed phase of $\mathrm{MgCl}_{2}$ hydrates, quantum mechanics (QM) calculations are performed in both periodic and non-periodic 
systems in order to generate a training set necessary to parameterize the new force field. DFT under the generalized gradient approximation (GGA) is used for the QM calculations. All the non-periodic $\mathrm{MgCl}_{2}$ hydrate clusters are relaxed in the framework of DFT implemented in Amsterdam Density Functional (ADF) program. ${ }^{34}$ The Perdew-Wang exchange and correlation functional (PW91) is used with a double polarized triple- $\zeta$ basis set. A similar GGA-DFT framework has been used to study the $\mathrm{CaCl}_{2}, \mathrm{MgCl}_{2}$, and $\mathrm{MgSO}_{4}$ hydrates. ${ }^{8,18,35}$ The bond dissociation energy for $\mathrm{Mg}-\mathrm{O}$ and $\mathrm{Mg}-\mathrm{Cl}$ bonds are obtained from GGA-DFT for $\mathrm{MgCl}_{2} \cdot \mathrm{H}_{2} \mathrm{O}$ and $\mathrm{MgCl}_{2} \cdot 2 \mathrm{H}_{2} \mathrm{O}$ as they are responsible for the hydrolysis and the dehydration reactions. Similarly, the angle bending energy curves in $\mathrm{MgCl}_{2}$ hydrates like $\mathrm{O}-\mathrm{Mg}-\mathrm{O}, \mathrm{Cl}-\mathrm{Mg}-$ $\mathrm{Cl}, \mathrm{H}-\mathrm{O}-\mathrm{Mg}$ are also obtained from GGA-DFT.

To simulate a reaction in solid phase of hydrates, the crystal structure of $\mathrm{MgCl}_{2}, \mathrm{MgCl}_{2} \cdot \mathrm{H}_{2} \mathrm{O}$, and $\mathrm{MgCl}_{2} \cdot 2 \mathrm{H}_{2} \mathrm{O}$ are compressed or stretched uniformly upto $20-30 \%$ of their relaxed volume to obtain the EOS. The periodic systems are relaxed in the framework of GGA-DFT using the VASP package. ${ }^{36}$ The projector augmented wave (PAW) method ${ }^{37}$ along with the Perdew Burke Ernzerhof (PBE) exchange-correlation functional ${ }^{38}$ is used under the GGA approximation. The Monkhorst-Pack $k$-point mesh is used to integrate the Brillouin zone of $\mathrm{MgCl}_{2}(5 \times 5 \times 3), \mathrm{MgCl}_{2} \cdot \mathrm{H}_{2} \mathrm{O}$ $(3 \times 5 \times 3)$, and $\mathrm{MgCl}_{2} \cdot 2 \mathrm{H}_{2} \mathrm{O}(4 \times 4 \times 8)$. The unit cell of crystals are fully relaxed with break condition for ionic relaxation of $10^{-6} \mathrm{eV}$ and plane wave cut off of $500 \mathrm{eV}$ using tetrahedron method with Blöchl corrections.

\subsection{Reactive force field and parameterization}

ReaxFF is a general bond-order-dependent many body empirical potential with a polarizable charge model that dynamically predicts a bond formation and dissociation during a reaction without connecting step function potentials. ${ }^{39}$ ReaxFF formalism represents a continuous landscape of energy which is dependent on the bond order and the non-bonded distance. The bond order is obtained from the inter-atomic distance and energy contribution updated with time. In the ReaxFF formalism, the total energy of the system can be partitioned into the following terms:

$$
\begin{aligned}
E_{\text {total }}= & E_{\text {bond }}+E_{\mathrm{val}}+E_{\text {tor }}+E_{\mathrm{lp}}+E_{\text {over } / \text { under }}+E_{\text {conj }} \\
& +E_{\text {H-bond }}+E_{\text {others }}+E_{\text {Coulomb }}+E_{\mathrm{vDW}} .
\end{aligned}
$$

$E_{\text {total }}$ is the overall interaction energy of the system, $E_{\text {Coulomb }}$ is the electrostatic contribution, and $E_{\text {bond }}$ is the bond energy. $E_{\mathrm{val}}$ and $E_{\text {tor }}$ are the three-body valence angle terms and the fourbody torsion terms respectively. $E_{\mathrm{lp}}$ and $E_{\text {over/under }}$ are the energy contributions from lone-pair electrons, and the penalty energy coming from over coordination and under coordination, $E_{\text {conj }}$ represents the conjugation energy term, $E_{\mathrm{H} \text {-bond }}$ represents the weak hydrogen bond and $E_{\text {others }}$ is introduced for other correcting types of species. $E_{\text {Coulomb }}$ and $E_{\mathrm{vDW}}$ are the nonbonded interactions between all pairs irrespective of the connectivity in the system. The Coulomb charge is calculated dynamically from the electro-negativity equalization method. ${ }^{39}$ Excessive electrostatic repulsions at very short interatomic distance are avoided by shielding parameters.
The ReaxFF parameters required to define the potential energy surface are optimized against the training set obtained from $\mathrm{QM}$ data. The initial $\mathrm{O} / \mathrm{H}$ parameters are taken from the iron-oxyhydroxide force field. ${ }^{40}$ The $\mathrm{O} / \mathrm{H}$ parameters are kept fixed while bond parameters of $\mathrm{Mg}-\mathrm{O}, \mathrm{Mg}-\mathrm{Cl}$ and angle parameters associated with these $\mathrm{Mg}$ and $\mathrm{Cl}$ are optimized. The optimization is done in such a way that optimized parameters are able to reproduce the energy and structural data present in the training set. The data in the training set used for comparison include bond dissociation energy, angle bending curve, reaction enthalpy and EOS for $\mathrm{MgCl}_{2}, \mathrm{MgCl}_{2} \cdot \mathrm{H}_{2} \mathrm{O}$, and $\mathrm{MgCl}_{2}$. $2 \mathrm{H}_{2} \mathrm{O}$. In an optimization process, ReaxFF parameters are varied such that the cumulative error $(\Xi)$ between the DFT data in the training set and their corresponding values obtained from ReaxFF is minimized. The cumulative error is defined as

$$
\Xi=\sum_{i=1}^{n}\left[\frac{X_{i, \mathrm{DFT}}-X_{i, \mathrm{ReaxFF}}}{\sigma_{i}}\right]^{2} .
$$

In this equation, $X_{i, \mathrm{DFT}}$ is the DFT value in the training set for data point $i$, and $X_{i, \text { ReaxFF }}$ is the corresponding value obtained by ReaxFF. $\sigma_{i}$ is a weight assigned to the $i$ th data point to set its relative importance compared to other data points. In a singleparameter search algorithm, ${ }^{32}$ a parabolic extrapolation method is used for parameterization. Further, we have used an MMC algorithm $^{33}$ to attain global minima of the cumulative error as ReaxFF parameters are correlated. In the MMC algorithm multiple parameters are changed with a random movement at every iteration and the proposed configuration is accepted with a probability given by

$$
P=\min \left[1, \exp ^{-\left(\frac{E_{\text {old }}-E_{\text {new }}}{k_{\mathrm{B}} T}\right)}\right] .
$$

$E_{\text {new }}$ is the error from the new set of parameter proposition and $E_{\text {old }}$ from the old set. $T$ is an artificial temperature which gradually decreases after each iteration (simulated annealing) and $k_{\mathrm{B}}$ is the Boltzmann constant. The MMC algorithm has shown a good agreement between QM and ReaxFF data for $\mathrm{MgSO}_{4}$ hydrates systems. ${ }^{33}$

\subsection{Diffusion}

The DC of $\mathrm{H}_{2} \mathrm{O}$ molecules through the $\mathrm{MgCl}_{2}$ hydrate crystal is obtained from the GK formulation described as

$$
D=\frac{1}{3} \int_{0}^{\infty}\langle v(t) \cdot v(0)\rangle \mathrm{d} t .
$$

$D$ is the diffusion coefficient of water molecules. The expression $\langle v(t) \cdot v(0)\rangle$ is known as the velocity autocorrelation function (VAF). ${ }^{41}$ The DC of $\mathrm{H}_{2} \mathrm{O}$ molecules through the $\mathrm{MgCl}_{2}$ hydrate crystals is obtained in a spherical control volume of radius $R$ in such a way that the crystal slab resides completely in the sphere and the center of mass of this slab is chosen as the center of the sphere as shown in Fig. 9. The motion of the relatively heavy $\mathrm{O}$ atom in a water molecule determines the trajectory of the $\mathrm{H}_{2} \mathrm{O}$ molecule as the center of mass of the $\mathrm{H}_{2} \mathrm{O}$ molecule coincides with that of the $\mathrm{O}$ atom. 


\section{Results and discussion}

\subsection{Force field parameterization results}

The initial force field parameters are optimized against hydrated $\mathrm{Cl}^{-}$ion and $\mathrm{MgCl}_{2}$ condensed phase data. The bond dissociation energies for $\mathrm{Mg}-\mathrm{Cl}$ and $\mathrm{Mg}-\mathrm{O}$ bonds present in $\mathrm{MgCl}_{2}, \mathrm{MgCl}_{2} \cdot \mathrm{H}_{2} \mathrm{O}$, and $\mathrm{MgCl}_{2} \cdot 2 \mathrm{H}_{2} \mathrm{O}$ gas molecules are obtained from restrained GGA-DFT calculations. Bond dissociation energy is the relative energy of the constrained molecule (specific bond constrain) with respect to its relaxed geometry. Similarly, angle bending curves for $\mathrm{Cl}-\mathrm{Mg}-\mathrm{Cl}, \mathrm{O}-\mathrm{Mg}-\mathrm{O}, \mathrm{O}-\mathrm{Mg}-\mathrm{Cl}$, and $\mathrm{H}-\mathrm{O}-\mathrm{Mg}$ are obtained from GGA-DFT. The single-parameter search algorithm $^{32}$ approaches a global minimum when the initial ReaxFF parameters are chosen close to that minimum while the multiparameter MMC algorithm ${ }^{33}$ approaches the global minimum irrespective of the initial guess. The bond and angle parameters are optimized with the single-parameter search ${ }^{32}$ followed by the multi-parameter MMC algorithm ${ }^{33}$ such that the trained parameters can reproduce the training set data accurately and the cumulative error attains a global minimum.

The optimized ReaxFF parameters are able to reproduce the bond dissociation curve of $\mathrm{Mg}-\mathrm{O}$ and $\mathrm{Mg}-\mathrm{Cl}$ bond present in $\mathrm{MgCl}_{2} \cdot \mathrm{H}_{2} \mathrm{O}$ and $\mathrm{MgCl}_{2} \cdot 2 \mathrm{H}_{2} \mathrm{O}$ as shown in Fig. 1 and 2 remarkably well, particularly near the minimum. The shape of the $\mathrm{Mg}-\mathrm{O}$ dissociation curve obtained from ReaxFF slightly differs from the DFT one. This discrepancy can be explained from the fact that there are many conformers of similar energy existing at the same $\mathrm{Mg}-\mathrm{O}$ distance due to the weak bonded interaction of $\mathrm{H}_{2} \mathrm{O}$ with $\mathrm{MgCl}_{2}$ and to the relatively strong non-bonded interaction in $\mathrm{MgCl}_{2} \cdot \mathrm{H}_{2} \mathrm{O}$ and $\mathrm{MgCl}_{2} \cdot 2 \mathrm{H}_{2} \mathrm{O}$. The optimized ReaxFF is also able to capture the angle bending energy curves for $\mathrm{MgCl}_{2} \cdot \mathrm{H}_{2} \mathrm{O}$ and $\mathrm{MgCl}_{2} \cdot 2 \mathrm{H}_{2} \mathrm{O}$ (see $\mathrm{ESI} \dagger$ ). The enthalpy change in the dehydration and in the hydrolysis reactions (gas phase) for $\mathrm{MgCl}_{2} \cdot \mathrm{H}_{2} \mathrm{O}$ and $\mathrm{MgCl}_{2} \cdot 2 \mathrm{H}_{2} \mathrm{O}$ are obtained from DFT. ReaxFF is also able to capture the enthalpy change in the dehydration and hydrolysis reaction of $\mathrm{MgCl}_{2} \cdot \mathrm{H}_{2} \mathrm{O}$ and $\mathrm{MgCl}_{2} \cdot 2 \mathrm{H}_{2} \mathrm{O}$ with a maximum difference of $5.5 \mathrm{kcal} \mathrm{mol}^{-1}$ (28\% of DFT value) as shown in Fig. 3 .

To predict the kinetics of solid $\mathrm{MgCl}_{2} \cdot \mathrm{H}_{2} \mathrm{O}$ and $\mathrm{MgCl}_{2} \cdot 2 \mathrm{H}_{2} \mathrm{O}$, the EOS is essential. The optimized force field, which is able to describe the gas phase reactions accurately, is further optimized with

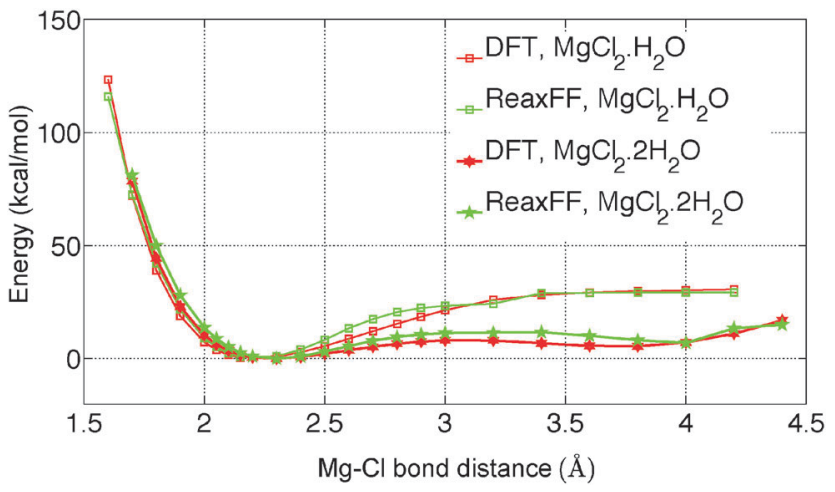

Fig. 1 Comparison of the $\mathrm{Mg}-\mathrm{Cl}$ bond dissociation energy curve in $\mathrm{MgCl}_{2}$ hydrates obtained from DFT and ReaxFF.

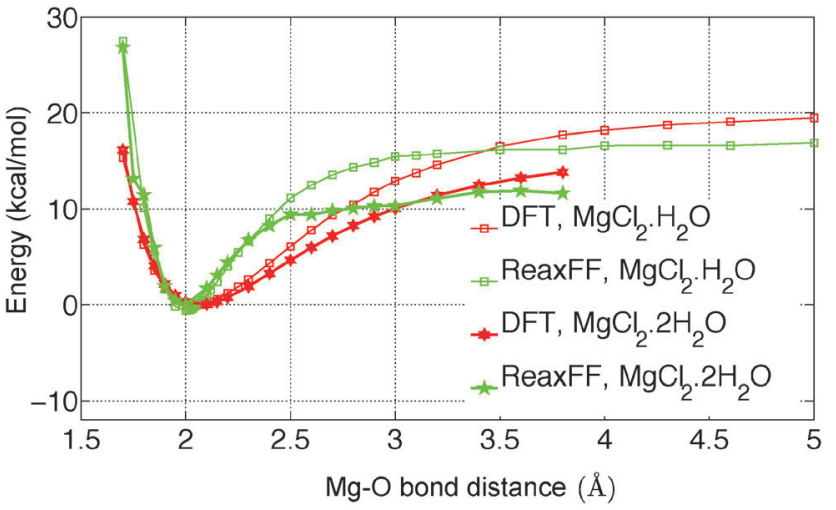

Fig. 2 Comparison of the $\mathrm{Mg}-\mathrm{O}$ bond dissociation energy curve in $\mathrm{MgCl}_{2}$ hydrates obtained from DFT and ReaxFF.

a condensed phase EOS of $\mathrm{MgCl}_{2}$ hydrates obtained from DFT in VASP. $^{36}$ The parameterized force field is also able to predict the experimentally observed crystal structures of $\mathrm{MgCl}_{2},{ }^{42} \mathrm{MgCl}_{2} \cdot \mathrm{H}_{2} \mathrm{O},{ }^{43}$ and $\mathrm{MgCl}_{2} \cdot 2 \mathrm{H}_{2} \mathrm{O}^{44}$ as shown in Table 1 . In Table 1 (rows 1-6), it can be observed that ReaxFF reproduces the lattice parameters of the unit cell of $\mathrm{MgCl}_{2}, \mathrm{MgCl}_{2} \cdot \mathrm{H}_{2} \mathrm{O}$ and $\mathrm{MgCl}_{2} \cdot 2 \mathrm{H}_{2} \mathrm{O}$ with great accuracy. ReaxFF is also able to reproduce the EOS for $\mathrm{MgCl}_{2}, \mathrm{MgCl}_{2} \cdot \mathrm{H}_{2} \mathrm{O}$ and $\mathrm{MgCl}_{2} \cdot 2 \mathrm{H}_{2} \mathrm{O}$ as shown in Fig. 4-6.

The bulk modulus is obtained from fitting the Birch-Murnaghan equation of state with the EOS obtained from DFT and ReaxFF. The bulk modulus $\left(B_{0}\right)$ and its first order derivative with respect to pressure $\left(B_{0}{ }^{\prime}\right)$ (rows 7 and 8 of Table 1) is obtained from ReaxFF and found to be in good agreement with DFT results for $\mathrm{MgCl}_{2}$, $\mathrm{MgCl}_{2} \cdot \mathrm{H}_{2} \mathrm{O}$ and $\mathrm{MgCl}_{2} \cdot 2 \mathrm{H}_{2} \mathrm{O}$.

\subsection{Proton transfer reaction}

Hydrolysis is an irreversible reaction which is usually observed in $\mathrm{MgCl}_{2} \cdot \mathrm{H}_{2} \mathrm{O}$ and $\mathrm{MgCl}_{2} \cdot 2 \mathrm{H}_{2} \mathrm{O}$. Wang and $\mathrm{Chen}^{16}$ have studied the thermolysis mechanism of $\mathrm{MgCl}_{2} \cdot \mathrm{H}_{2} \mathrm{O}$ using a semi-empirical PM3 method. They observed that proton transfer is an important step in the hydrolysis reaction. To understand the reaction path for the proton transfer in $\mathrm{MgCl}_{2} \cdot 2 \mathrm{H}_{2} \mathrm{O}$, the relative energy of a

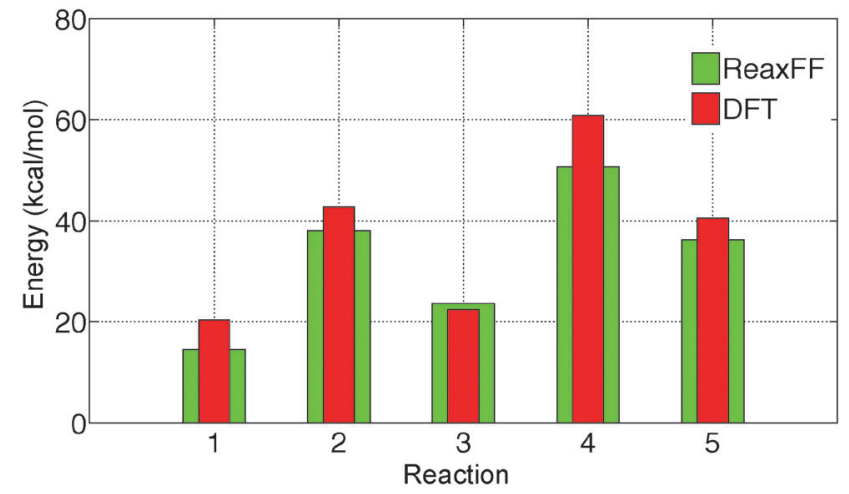

Fig. 3 Comparison of change in reaction enthalpy for the dehydration and the hydrolysis reactions obtained from DFT and ReaxFF. The indices on the $X$ axis represent the following reactions: (1) $\mathrm{MgCl}_{2} \cdot 2 \mathrm{H}_{2} \mathrm{O} \rightarrow \mathrm{MgCl}_{2} \cdot \mathrm{H}_{2} \mathrm{O}+\mathrm{H}_{2} \mathrm{O}$ (2) $\mathrm{MgCl}_{2} \cdot 2 \mathrm{H}_{2} \mathrm{O} \rightarrow \mathrm{MgCl}_{2}+2 \mathrm{H}_{2} \mathrm{O}$ (3) $\mathrm{MgCl}_{2} \cdot \mathrm{H}_{2} \mathrm{O} \rightarrow \mathrm{MgCl}_{2}+\mathrm{H}_{2} \mathrm{O}$ (4) $\mathrm{MgCl}_{2}$. $2 \mathrm{H}_{2} \mathrm{O} \rightarrow \mathrm{MgOHCl}+\mathrm{HCl}+\mathrm{H}_{2} \mathrm{O}$ (5) $\mathrm{MgCl}_{2} \cdot \mathrm{H}_{2} \mathrm{O} \rightarrow \mathrm{MgOHCl}+\mathrm{HCl}$. 
Table 1 Comparison of computed lattice parameters and elastic properties of $\mathrm{MgCl}_{2}, \mathrm{MgCl}_{2} \cdot \mathrm{H}_{2} \mathrm{O}$, and $\mathrm{MgCl}_{2} \cdot 2 \mathrm{H}_{2} \mathrm{O}$ from DFT and ReaxFF. The value given in the parenthesis represents the experimental data ${ }^{42-44}$

\begin{tabular}{|c|c|c|c|c|c|c|}
\hline & \multicolumn{2}{|l|}{$\underline{\mathrm{MgCl}_{2}}$} & \multicolumn{2}{|c|}{$\underline{\mathrm{MgCl}_{2} \cdot \mathrm{H}_{2} \mathrm{O}}$} & \multicolumn{2}{|c|}{$\underline{\mathrm{MgCl}_{2} \cdot 2 \mathrm{H}_{2} \mathrm{O}}$} \\
\hline$a(\AA)$ & 3.665 & $3.662[3.596]^{42}$ & 8.936 & $8.936[8.917]^{43}$ & 7.649 & $7.672[7.389]^{44}$ \\
\hline$c(\AA)$ & 19.860 & $19.840[17.589]^{42}$ & 11.592 & $11.593[11.477]^{43}$ & 3.694 & $3.705[3.648]^{44}$ \\
\hline$\alpha\left(^{0}\right)$ & 90 & $90[90]^{42}$ & 90 & $90[90]^{43}$ & 90 & $90[90]$ \\
\hline$\beta\left(^{\circ}\right)$ & 90 & $90[90]^{42}$ & 90 & $90[90]^{43}$ & 102.46 & $102.45[98.96]$ \\
\hline
\end{tabular}

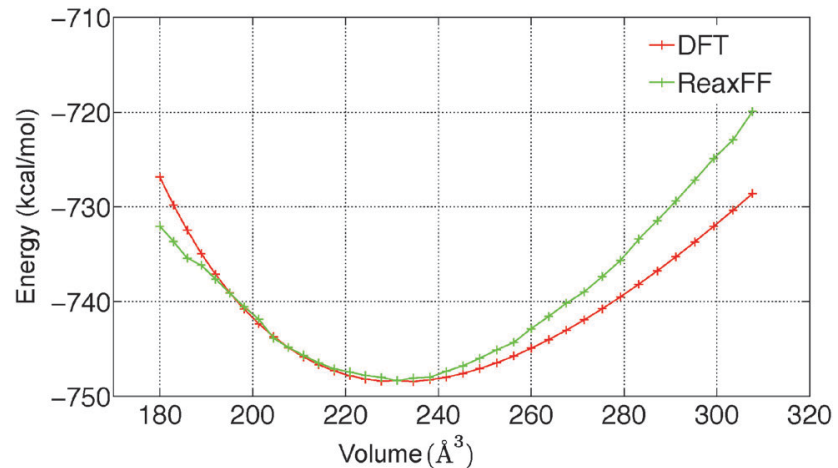

Fig. 4 Comparison of the EOS for $\mathrm{MgCl}_{2}$ obtained from DFT and ReaxFF.

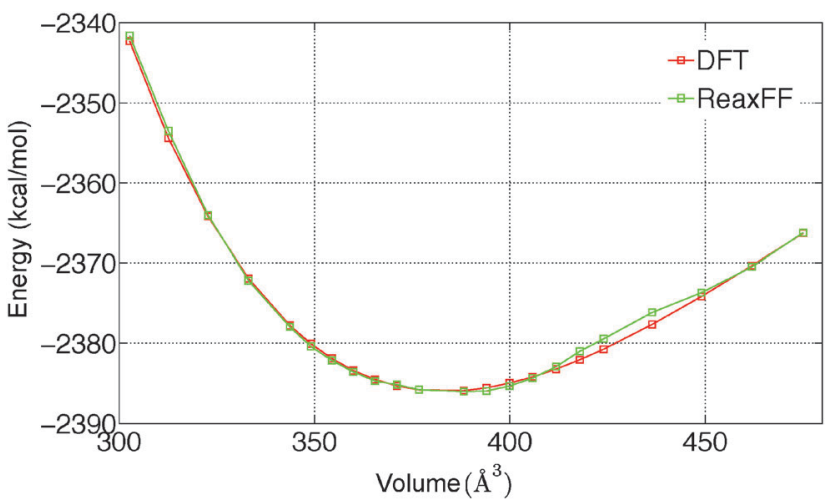

Fig. 5 Comparison of the EOS for $\mathrm{MgCl}_{2} \cdot \mathrm{H}_{2} \mathrm{O}$ obtained from DFT and ReaxFF.

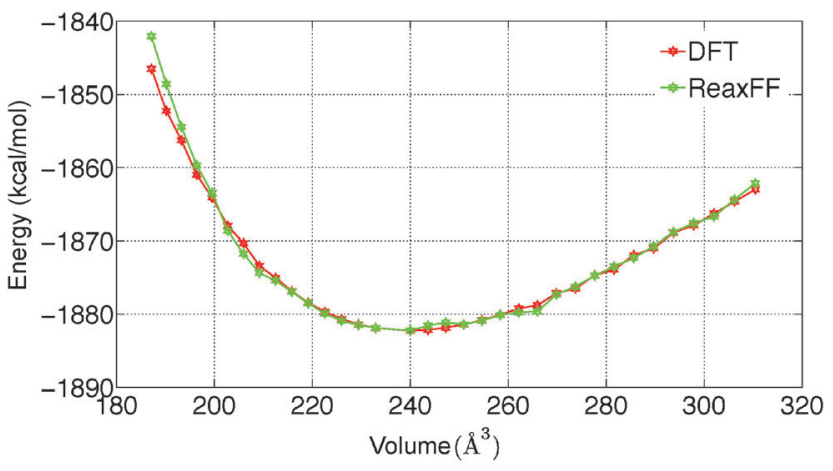

Fig. 6 Comparison of the EOS for $\mathrm{MgCl}_{2} \cdot 2 \mathrm{H}_{2} \mathrm{O}$ obtained from DFT and ReaxFF.
$\mathrm{MgCl}_{2} \cdot 2 \mathrm{H}_{2} \mathrm{O}$ molecule is obtained from GGA-DFT calculations by constraining the $\mathrm{O}-\mathrm{H}$ bond lengths, which is shown in Fig. 7(a). We obtained a barrier of $19.55 \mathrm{kcal} \mathrm{mol}^{-1}$ for proton transfer in gaseous $\mathrm{MgCl}_{2} \cdot 2 \mathrm{H}_{2} \mathrm{O}$ and a barrier of $8.31 \mathrm{kcal} \mathrm{mol}^{-1}$ for chloride ion $\left(\mathrm{Cl}^{-}\right)$formation, which indicates that proton transfer is a rate determining step in the hydrolysis reaction. To validate the applicability of the ReaxFF, we obtained the reaction path for proton transfer in gaseous $\mathrm{MgCl}_{2} \cdot 2 \mathrm{H}_{2} \mathrm{O}$ from ReaxFF and compared it with DFT. From Fig. 8, it can be observed that ReaxFF is able to predict the barrier for proton transfer (20.24 kcal mol${ }^{-1}$ ) and the reaction coordinate for proton transfer in $\mathrm{MgCl}_{2} \cdot 2 \mathrm{H}_{2} \mathrm{O}$.

To understand the effect of a neighboring $\mathrm{H}_{2} \mathrm{O}$ molecule in proton transfer of $\mathrm{MgCl}_{2} \cdot 2 \mathrm{H}_{2} \mathrm{O}$, a $\mathrm{H}_{2} \mathrm{O}$ molecule is placed nearby as shown in Fig. 7(b). A barrier of $29.61 \mathrm{kcal} \mathrm{mol}^{-1}$ is obtained from DFT for proton transfer in $\mathrm{MgCl}_{2} \cdot 2 \mathrm{H}_{2} \mathrm{O}$ surrounded by one $\mathrm{H}_{2} \mathrm{O}$ molecule. This explains the lower hydrolysis in the higher hydrates (tetra and hexa) of $\mathrm{MgCl}_{2}$, as the neighboring $\mathrm{H}_{2} \mathrm{O}$ molecule increases the barrier for proton transfer and inhibits the hydrolysis. A barrier of $26.54 \mathrm{kcal} \mathrm{mol}^{-1}$ for proton transfer is obtained from ReaxFF, which is in agreement with the DFT result $\left(29.61 \mathrm{kcal} \mathrm{mol}^{-1}\right)$. The position of the transition state predicted from ReaxFF differs by $0.5 \AA$ A because surrounding $\mathrm{H}_{2} \mathrm{O}$ molecule may form many structures of similar energy (see ESI $\dagger$ ).

\subsection{ReaxFF-MD simulations of $\mathrm{MgCl}_{2}$ hydrates}

In the present study, we have investigated the kinetics of dehydration and hydrolysis reactions of solid $\mathrm{MgCl}_{2} \cdot \mathrm{H}_{2} \mathrm{O}$ and $\mathrm{MgCl}_{2} \cdot 2 \mathrm{H}_{2} \mathrm{O}$.

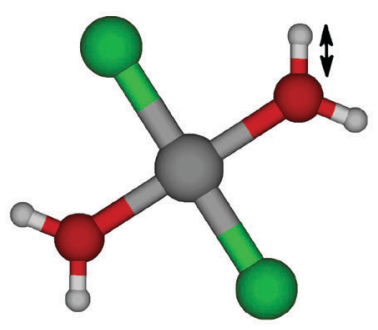

(a) $\mathrm{MgCl}_{2} \cdot 2 \mathrm{H}_{2} \mathrm{O}$

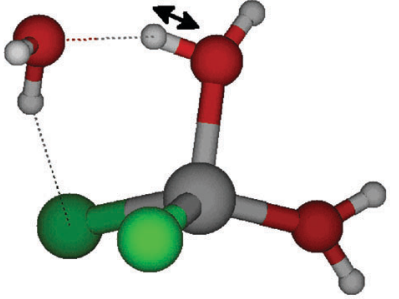

(b) $\mathrm{MgCl}_{2} \cdot 2 \mathrm{H}_{2} \mathrm{O}+\mathrm{H}_{2} \mathrm{O}$
Fig. 7 The initial optimized structure of $\mathrm{MgCl}_{2} \cdot 2 \mathrm{H}_{2} \mathrm{O}$ molecules used to obtain the reaction path of proton transfer from DFT and ReaxFF. $\mathrm{MgCl}_{2}$. $2 \mathrm{H}_{2} \mathrm{O}$ is represented using the ball-and-stick model. Color scheme: $\mathrm{Mg}=$ grey, $\mathrm{O}=$ red, $\mathrm{H}=$ white, and $\mathrm{Cl}=$ green . 


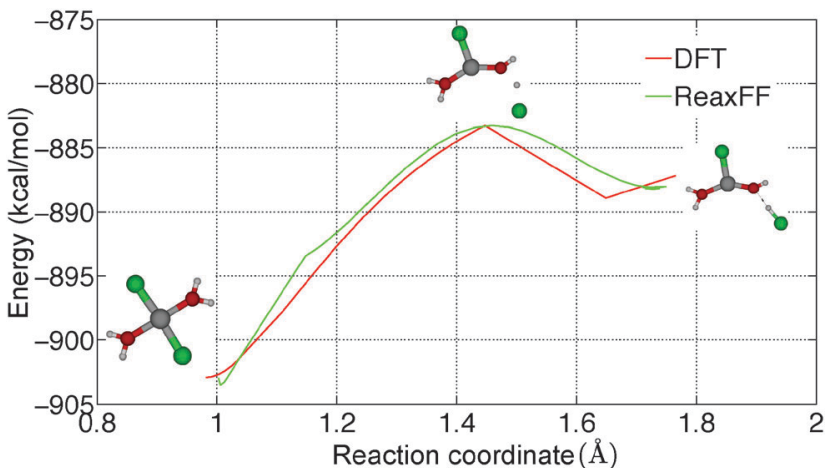

Fig. 8 Comparison of barriers for proton transfer in $\mathrm{MgCl}_{2} \cdot 2 \mathrm{H}_{2} \mathrm{O}$ obtained from DFT and ReaxFF. $\mathrm{MgCl}_{2} \cdot 2 \mathrm{H}_{2} \mathrm{O}$ is represented using the ball-and-stick model. Color scheme: $\mathrm{Mg}=$ grey, $\mathrm{O}=$ red, $\mathrm{H}=$ white, and $\mathrm{Cl}=$ green.

We created the $3 \times 6 \times 6$ super-cell of $\mathrm{MgCl}_{2} \cdot \mathrm{H}_{2} \mathrm{O}$ crystal ${ }^{43}$ and $6 \times 6 \times 6$ super-cell of $\mathrm{MgCl}_{2} \cdot 2 \mathrm{H}_{2} \mathrm{O}^{44}$ from their experimental crystallographic information file (CIF). ${ }^{45}$ 2D-periodic slabs of $26.8 \times$ $21.8 \times 1000 \AA$ for $\mathrm{MgCl}_{2} \cdot \mathrm{H}_{2} \mathrm{O}$ (as shown in Fig. 13a) and $44.3 \times$ $1000 \times 21.9 \AA$ for $\mathrm{MgCl}_{2} \cdot 2 \mathrm{H}_{2} \mathrm{O}$ (as shown in Fig. 9a) are prepared from the super-cell by eliminating periodicity in the $Z$ and $Y$ direction respectively. The removal of periodicity is chosen is a direction parallel to the $\mathrm{Mg}-\mathrm{O}$ bond as the $\mathrm{Mg}-\mathrm{O}$ bond is weaker than the $\mathrm{Mg}-\mathrm{Cl}$ bond. We carried out NVT-MD simulations at various temperatures using the Berendsen thermostat with a temperature damping constant of 100 femtosecond. The MD time step of 0.25 femtosecond is used for $\mathrm{MgCl}_{2} \cdot \mathrm{H}_{2} \mathrm{O}$ and $\mathrm{MgCl}_{2} \cdot 2 \mathrm{H}_{2} \mathrm{O}$. All simulations are performed upto 1 nanosecond and average number of molecules are recorded from last 500 picosecond.

3.3.1 Force field validation. To validate ReaxFF, the radial distribution function (RDF) calculated from the MD simulations (upto 250 picosecond) for $\mathrm{O}-\mathrm{H}, \mathrm{Mg}-\mathrm{O}$, and $\mathrm{Mg}-\mathrm{Cl}$ in 2D periodic slabs of $\mathrm{MgCl}_{2} \cdot \mathrm{H}_{2} \mathrm{O}, \mathrm{MgCl}_{2} \cdot 2 \mathrm{H}_{2} \mathrm{O}$ are calculated and shown in Fig. 10. The peak location for $\mathrm{O}-\mathrm{H}$ pair is observed at $1.02 \AA$ which is close to the $\mathrm{O}-\mathrm{H}$ bond length $(0.98 \AA)$ reported earlier in the experimental unit cell of $\mathrm{MgCl}_{2} \cdot \mathrm{H}_{2} \mathrm{O} \cdot{ }^{43}$ A similar peak location was reported from the ReaxFF parameters of Lindqvist Polyoxoanion in Bulk Water. ${ }^{46}$

The first peak location for the $\mathrm{Mg}-\mathrm{O}$ pair is observed at $2.0 \AA$, which represents the $\mathrm{Mg}-\mathrm{O}$ atomic bond as shown in Fig. 10. The corresponding distance in the experimental unit cell of $\mathrm{MgCl}_{2} \cdot 2 \mathrm{H}_{2} \mathrm{O}$ is $2.0 \AA^{44}{ }^{44}$ The second peak location for $\mathrm{Mg}-\mathrm{O}$ pair is observed at $4.4 \AA$, which represents the non-bonded $\mathrm{Mg}$ attractions with the $\mathrm{H}_{2} \mathrm{O}$ molecule of the adjacent $\mathrm{MgCl}_{2}$ hydrate as shown in Fig. 10. The corresponding distance in the experimental unit cell of $\mathrm{MgCl}_{2} \cdot 2 \mathrm{H}_{2} \mathrm{O}$ is $4.0 \AA^{44}$ in this case.

The first peak location for $\mathrm{Mg}-\mathrm{Cl}$ pair is observed at $2.3 \AA$ which represents the $\mathrm{Mg}-\mathrm{Cl}$ bond. The corresponding distances in the experimental unit cell of $\mathrm{MgCl}_{2} \cdot \mathrm{H}_{2} \mathrm{O}$ and $\mathrm{MgCl}_{2}$. $2 \mathrm{H}_{2} \mathrm{O}$ are $2.56 \AA^{43,44}$ The second peak is observed at $4.3 \AA$ and $4.7 \AA$ for $\mathrm{MgCl}_{2} \cdot \mathrm{H}_{2} \mathrm{O}$ and $\mathrm{MgCl}_{2} \cdot 2 \mathrm{H}_{2} \mathrm{O}$ which represents the $\mathrm{Mg}$ attraction with $\mathrm{Cl}$ of the adjacent $\mathrm{MgCl}_{2}$ hydrate molecule as shown in Fig. 10. The corresponding distances in the experimental unit cell of $\mathrm{MgCl}_{2} \cdot \mathrm{H}_{2} \mathrm{O}$ and $\mathrm{MgCl}_{2} \cdot 2 \mathrm{H}_{2} \mathrm{O}$ are $4.5 \AA^{43}$ and $4.8 \AA{ }^{44}$ respectively. We conclude that ReaxFF parameters obtained from the present study are consistent with DFT results and experimental results in representing the bonded and nonbonded interactions.

3.3.2 Dehydration reaction. The dehydration kinetics of $\mathrm{MgCl}_{2} \cdot \mathrm{H}_{2} \mathrm{O}$ and $\mathrm{MgCl}_{2} \cdot 2 \mathrm{H}_{2} \mathrm{O}$ are investigated at various temperature $(300,350,400,450$, and $500 \mathrm{~K})$. This temperature range falls in the operating range of the TMC based seasonal heat storage systems. The average number of $\mathrm{H}_{2} \mathrm{O}$ molecules leaving from the solid slab of $\mathrm{MgCl}_{2} \cdot \mathrm{H}_{2} \mathrm{O}(26.8 \times 21.8 \times 1000 \AA)$ into the vacuum region ( $Z$ direction) is $21.38 \pm 4.45$ after 1000 picosecond at $300 \mathrm{~K}$. The average number of $\mathrm{H}_{2} \mathrm{O}$ molecules escaping from $\mathrm{MgCl}_{2} \cdot \mathrm{H}_{2} \mathrm{O}$ increases from $21.28 \pm 4.45$ to $75.43 \pm 9.08$ in the temperature range of 300 to $500 \mathrm{~K}$ as shown in Fig. 11. A molecular dehydration rate could be estimated from

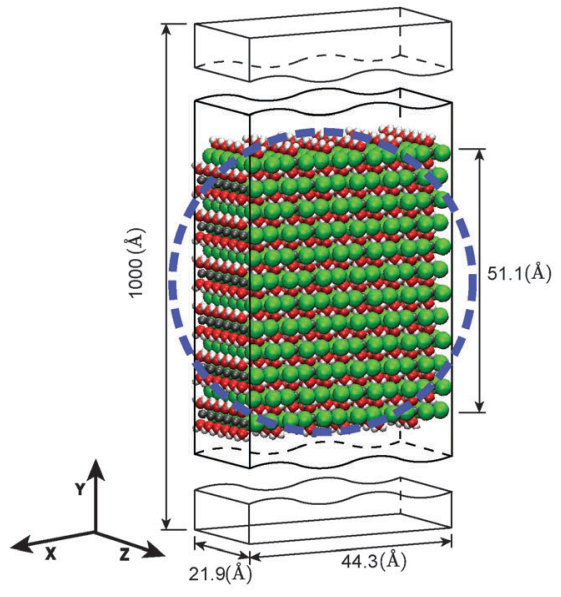

(a)

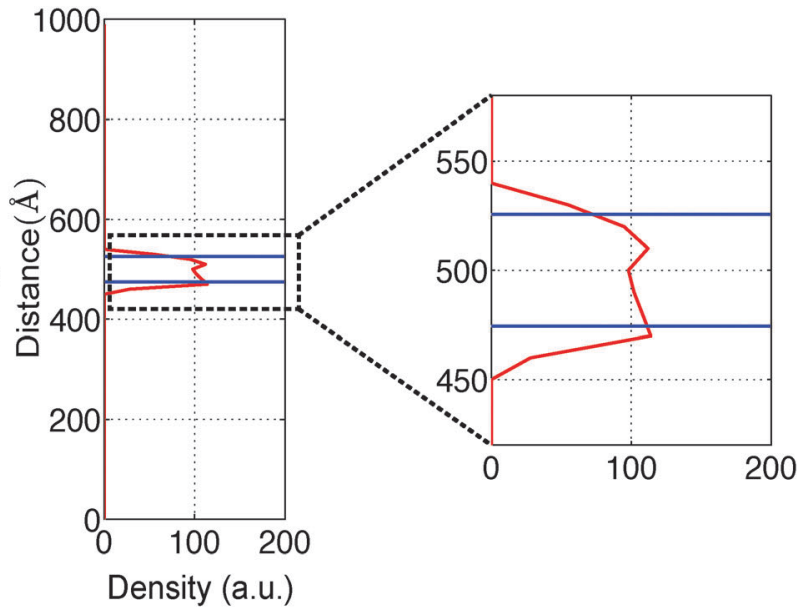

(b)

Fig. 9 A 2D periodic slab of $\mathrm{MgCl}_{2} \cdot 2 \mathrm{H}_{2} \mathrm{O}$ is used for ReaxFF-MD simulations (a) the initial configuration, the blue dotted sphere represents a control volume used for $\mathrm{H}_{2} \mathrm{O}$ diffusion using $\mathrm{GK}$ method. $\mathrm{MgCl}_{2} \cdot 2 \mathrm{H}_{2} \mathrm{O}$ is represented using the ball-and-stick model. Color scheme: $\mathrm{Mg}=\mathrm{grey}, \mathrm{O}=$ red, $\mathrm{H}=$ white, and $\mathrm{Cl}=$ green (b) average density distribution of $\mathrm{H}_{2} \mathrm{O}$ along the $\mathrm{Y}$ axis after $375 \mathrm{ps}$ at $300 \mathrm{~K}$. 

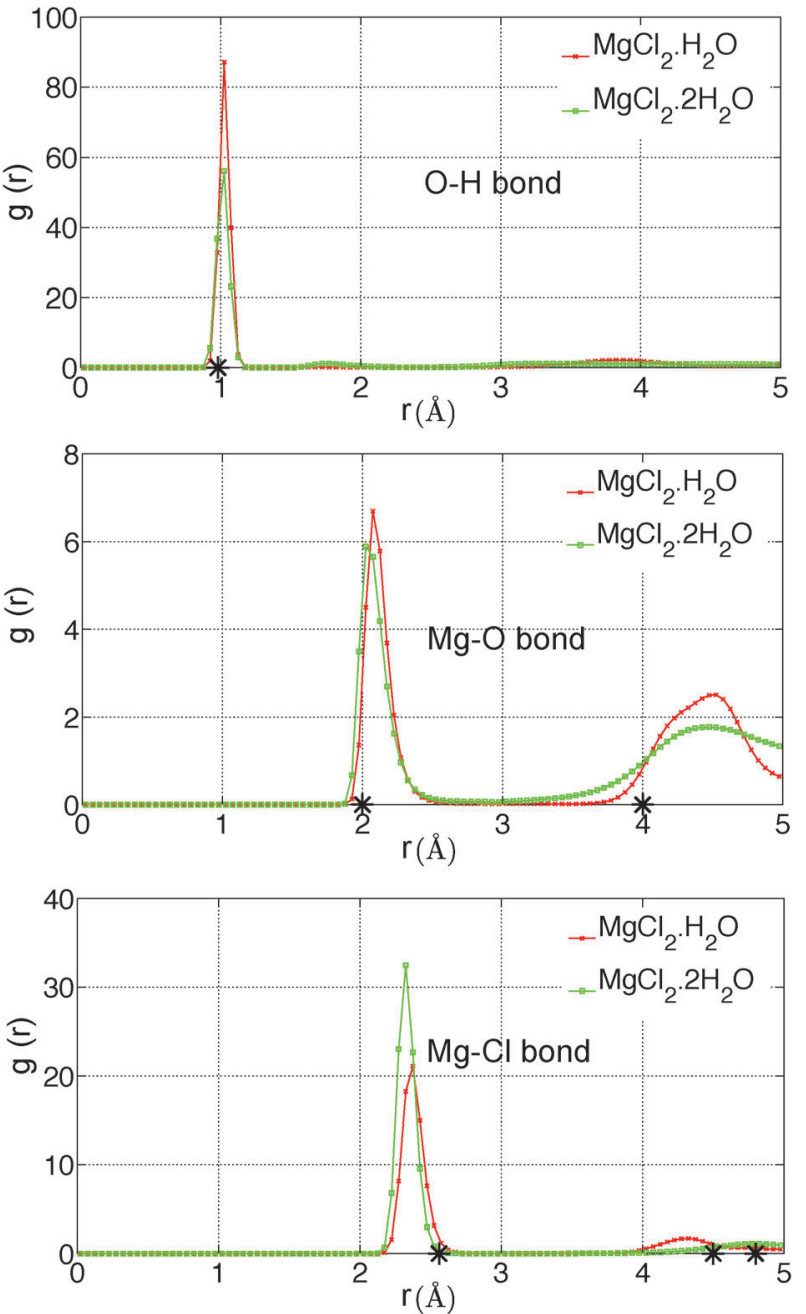

Fig. 10 Radial distribution functions of $\mathrm{O}-\mathrm{H}, \mathrm{Mg}-\mathrm{O}$, and $\mathrm{Mg}-\mathrm{Cl}$ bond in $\mathrm{MgCl}_{2} \cdot \mathrm{H}_{2} \mathrm{O}$ and $\mathrm{MgCl}_{2} \cdot 2 \mathrm{H}_{2} \mathrm{O}$ obtained with newly developed ReaxFF parameters of $\mathrm{MgCl}_{2}$ hydrates at $300 \mathrm{~K}$. The represents the corresponding distance in the experimental unit cell. ${ }^{43,44}$

the gradient of a linear fit. The dehydration rate keeps on increasing with temperature in the range of 300 to $500 \mathrm{~K}$ as shown in Fig. 11. The dehydration rate at $500 \mathrm{~K}$ is 3.1 times faster when compared to the rate at $300 \mathrm{~K}$.

The average number of $\mathrm{H}_{2} \mathrm{O}$ molecules leaving the solid slab of $\mathrm{MgCl}_{2} \cdot 2 \mathrm{H}_{2} \mathrm{O}(44.3 \times 1000 \times 21.9 \AA)$ into the vacuum region ( $Y$ direction) is $51.17 \pm 7.63$ after 750 picosecond. The system is further equilibrated upto 1000 picosecond and $\mathrm{H}_{2} \mathrm{O}$ average increased by 4.61. The average density distribution of $\mathrm{H}_{2} \mathrm{O}$ molecules are obtained by diving the simulation box into the bins of $10 \AA$ along the $Y$ axis as shown in Fig. 9b. Blue lines represent the initial boundaries. The water molecules which escape from the solid slab accumulate on the surface at $300 \mathrm{~K}$. There is a concentration gradient of $\mathrm{H}_{2} \mathrm{O}$ molecules present on the surface along the $Y$ axis. Thereby, confirms the influence of water diffusion on the dehydration process. The average number of $\mathrm{H}_{2} \mathrm{O}$ molecules escaping from $\mathrm{MgCl}_{2} \cdot 2 \mathrm{H}_{2} \mathrm{O}$ increases from $54.93 \pm 6.76$ to $71.66 \pm 7.27$ in the temperature range of 300 to $450 \mathrm{~K}$ as shown in Fig. 12. Further, increment in

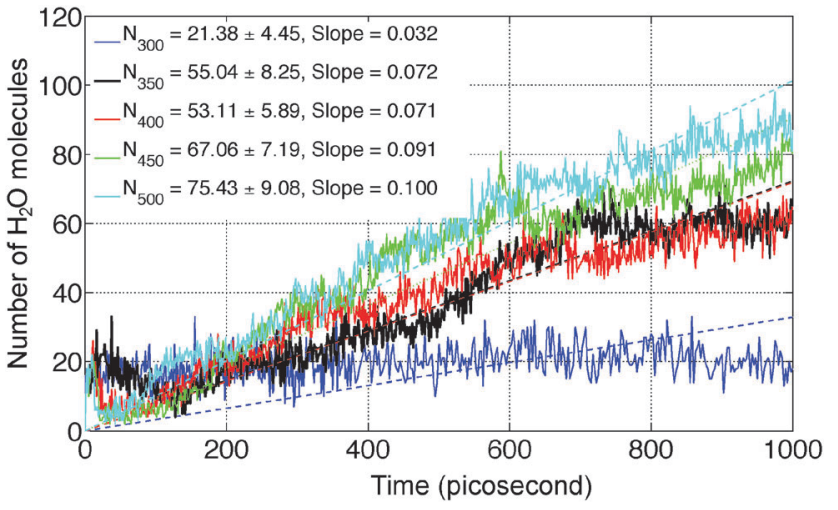

Fig. 11 Dehydration kinetics of $\mathrm{MgCl}_{2} \cdot \mathrm{H}_{2} \mathrm{O}$ in a 2D-periodic slab of $26.8 \times$ $21.8 \times 1000 \AA$ upto 1 nanosecond using ReaxFF-MD simulations. The solid lines represent the kinetics from ReaxFF-MD simulations while the dashed lines of the same color represent a linear fit to estimate the dehydration rate. $N_{T}$ is average number of $\mathrm{H}_{2} \mathrm{O}$ molecules escaping from the slab at temperature $T$.

temperature leads to reduction in the number of $\mathrm{H}_{2} \mathrm{O}$ molecules escaping from $\mathrm{MgCl}_{2} \cdot 2 \mathrm{H}_{2} \mathrm{O}$ to $50.73 \pm 5.85$ at $500 \mathrm{~K}$ as shown in Fig. 12. This reduction in number of water molecules escaping from solid slab of $\mathrm{MgCl}_{2} \cdot 2 \mathrm{H}_{2} \mathrm{O}$ could be explained from the fact that existing water molecules present in the vacuum region are pushing them back into the crystal. The effect of temperature on the dehydration of $\mathrm{MgCl}_{2} \cdot \mathrm{H}_{2} \mathrm{O}$ and $\mathrm{MgCl}_{2} \cdot 2 \mathrm{H}_{2} \mathrm{O}$ is similar to experiments. ${ }^{47}$

3.3.3 HCl formation. The $\mathrm{HCl}$ formation is investigated at various temperatures $(300,350,400,450$, and $500 \mathrm{~K})$. The first $\mathrm{HCl}$ molecule is observed from the 2D periodic slab of $\mathrm{MgCl}_{2} \cdot \mathrm{H}_{2} \mathrm{O}$ at $350 \mathrm{~K}$ after 136.25 picosecond. To narrow down the onset temperature of $\mathrm{HCl}$ formation, $\mathrm{MD}$ simulations are carried out at the interval of $10 \mathrm{~K}$ between $300-350 \mathrm{~K}$. The onset of $\mathrm{HCl}$ formation is observed at $340 \mathrm{~K}$ after 318.75 picosecond in $\mathrm{MgCl}_{2} \cdot \mathrm{H}_{2} \mathrm{O}$ as shown in Fig. 13b. After dehydration/hydrolysis, the crystal slab elongates along the vacuum direction as some of $\mathrm{MgCl}_{2}$ and $\mathrm{H}_{2} \mathrm{O}$ came out on the surface. The onset of $\mathrm{HCl}$ formation is experimentally ${ }^{23}$ observed in the temperature range of 343-353 K, which is in good agreement with the present ReaxFF study. The hydrolysis

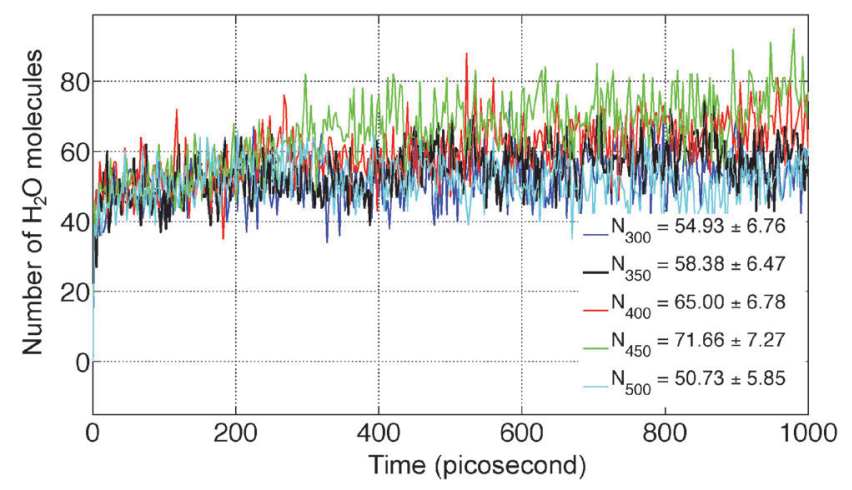

Fig. 12 Dehydration kinetics of $\mathrm{MgCl}_{2} \cdot 2 \mathrm{H}_{2} \mathrm{O}$ in a $2 \mathrm{D}$-periodic slab of $44.3 \times 1000 \times 21.9 \AA$ upto 1 nanosecond using ReaxFF-MD simulations. $N_{T}$ is average number of $\mathrm{H}_{2} \mathrm{O}$ molecules escaping from the slab at temperature $T$. 

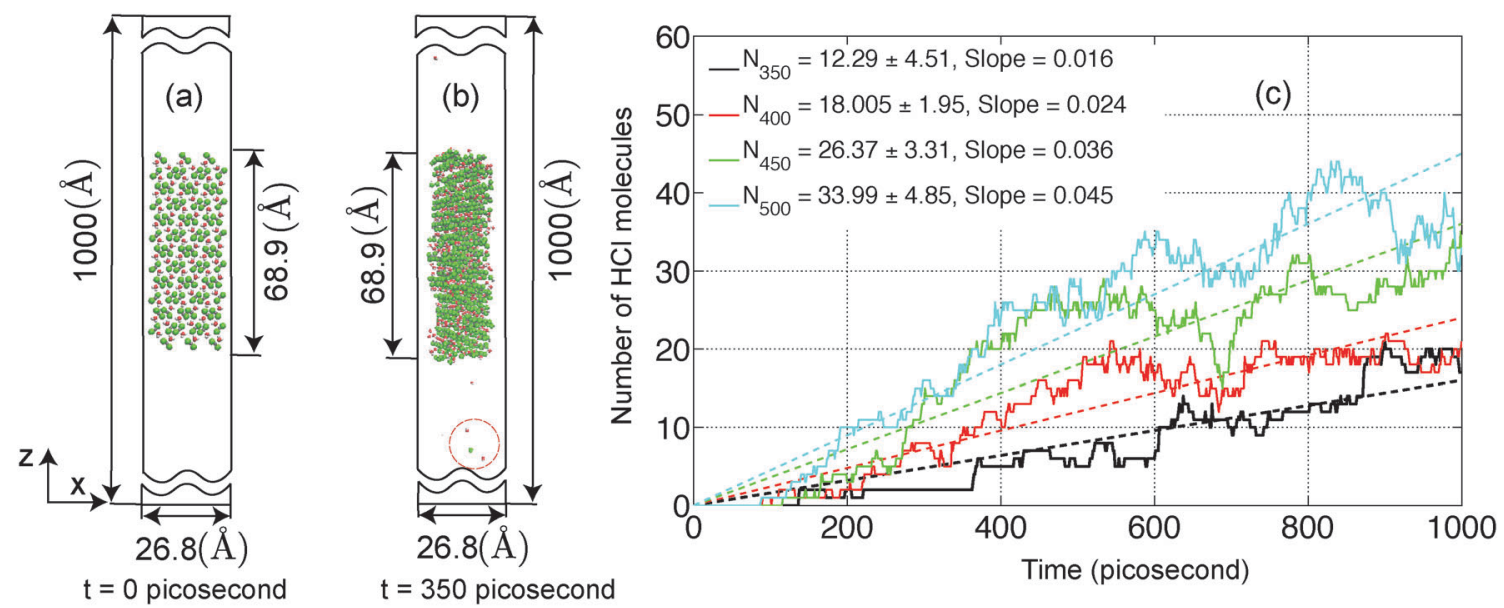

Fig. 13 Side view of $\mathrm{MgCl}_{2} \cdot \mathrm{H}_{2} \mathrm{O}$ in a 2D-periodic slab of $26.8 \times 21.8 \times 1000 \AA$ used in ReaxFF-MD simulations performed at $340 \mathrm{~K}$ (a) initial configuration at $t=0 \mathrm{~s}(\mathrm{~b})$ intermediate configuration at $t=350$ picosecond. The red dotted circle represents the area where first $\mathrm{HCl}$ formations occur. $\mathrm{MgCl}_{2} \cdot \mathrm{H}_{2} \mathrm{O}$ is represented using the ball-and-stick model. Color scheme: $\mathrm{Mg}=$ grey, $\mathrm{O}=$ red, $\mathrm{H}=$ white, and $\mathrm{Cl}=$ green (c) hydrolysis kinetics of $\mathrm{MgCl}_{2} \cdot \mathrm{H}_{2} \mathrm{O}$ upto 1 nanosecond. The solid line represents the kinetics from ReaxFF-MD simulation while the dashed line of the same color represents the linear fits to estimate the hydrolysis rate. $N_{T}$ is average number of $\mathrm{HCl}$ molecules escaping from the slab at temperature $T$.

kinetics of the $\mathrm{MgCl}_{2} \cdot \mathrm{H}_{2} \mathrm{O}$ is shown in Fig. 13c at different temperatures $(350-500 \mathrm{~K})$ upto 1000 picosecond. The number of $\mathrm{HCl}$ molecules keeps on increasing with temperature. The hydrolysis rate estimated from the linear fits keeps on increasing with temperature as shown in Fig. 13c. The hydrolysis rate at $500 \mathrm{~K}$ is 2.8 times faster when compared to the rate at $350 \mathrm{~K}$. Hydrolysis is not observed in $\mathrm{MgCl}_{2} \cdot 2 \mathrm{H}_{2} \mathrm{O}$ in the temperature range of $300-500 \mathrm{~K}$.

3.3.4 Effect of the temperature on the $\mathrm{H}_{2} \mathrm{O}$ transport. The diffusion of $\mathrm{H}_{2} \mathrm{O}$ through a crystalline structure of the solid salt hydrate is a complex phenomena as the $\mathrm{H}_{2} \mathrm{O}$ molecules resulting from dehydration reaction have to diffuse to the surface in order to dehydrate. The diffusivity of $\mathrm{H}_{2} \mathrm{O}$ is computed from ReaxFFMD simulations after 250 picosecond of equilibration time and 125 picosecond of production time at various temperatures $(300,350,400,450$, and $500 \mathrm{~K})$. The DC of $\mathrm{H}_{2} \mathrm{O}$ in $\mathrm{MgCl}_{2} \cdot \mathrm{H}_{2} \mathrm{O}$ is $7.18 \times 10^{-11} \mathrm{~m}^{2} \mathrm{~s}^{-1}$ at $300 \mathrm{~K}$. The reported DCs in the present study are well converged with VAF interval.

To estimate the statistical error in the $\mathrm{DC}$ of $\mathrm{H}_{2} \mathrm{O}$ through 2D periodic slabs of $\mathrm{MgCl}_{2} \cdot \mathrm{H}_{2} \mathrm{O}$ and $\mathrm{MgCl}_{2} \cdot 2 \mathrm{H}_{2} \mathrm{O}$, five repetitions of ReaxFF-MD simulations are performed with the same parameters at $300 \mathrm{~K}$. The average diffusivity of $\mathrm{H}_{2} \mathrm{O}$ through $\mathrm{MgCl}_{2} \cdot \mathrm{H}_{2} \mathrm{O}$ is $7.46 \pm 0.77 \times 10^{-11} \mathrm{~m}^{2} \mathrm{~s}^{-1}$ and $1.14 \pm 0.15 \times 10^{-10} \mathrm{~m}^{2} \mathrm{~s}^{-1}$ for $\mathrm{MgCl}_{2} \cdot 2 \mathrm{H}_{2} \mathrm{O}$. The DCs in $\mathrm{MgCl}_{2} \cdot \mathrm{H}_{2} \mathrm{O}$ and $\mathrm{MgCl}_{2} \cdot 2 \mathrm{H}_{2} \mathrm{O}$ are 0.03 and 0.04 times the DC of bulk water. ${ }^{48}$ In the lack of

Table 2 The diffusion coefficient of water through 2D-periodic slabs at different temperature after 375 picosecond

\begin{tabular}{lll}
\hline $\begin{array}{l}\text { Temperature, } \\
T, \mathrm{~K}\end{array}$ & $\begin{array}{l}\text { Diffusivity in } \\
\mathrm{MgCl}_{2} \cdot \mathrm{H}_{2} \mathrm{O}, \mathrm{m}^{2} \mathrm{~s}^{-1}\end{array}$ & $\begin{array}{l}\text { Diffusivity in } \\
\mathrm{MgCl}_{2} \cdot 2 \mathrm{H}_{2} \mathrm{O}, \mathrm{m}^{2} \mathrm{~s}^{-1}\end{array}$ \\
\hline 300 & $6.99 \times 10^{-11}$ & $1.16 \times 10^{-10}$ \\
350 & $7.02 \times 10^{-11}$ & $3.18 \times 10^{-10}$ \\
400 & $9.13 \times 10^{-11}$ & $9.54 \times 10^{-10}$ \\
450 & $6.95 \times 10^{-10}$ & $2.78 \times 10^{-9}$ \\
500 & $4.47 \times 10^{-9}$ & $6.66 \times 10^{-9}$
\end{tabular}

experimental study for the diffusion of $\mathrm{H}_{2} \mathrm{O}$ through $\mathrm{MgCl}_{2}$ hydrates, we compared with the $\mathrm{H}_{2} \mathrm{O}$ diffusivity through other TCM epsomite $\left(\mathrm{MgSO}_{4} \cdot 7 \mathrm{H}_{2} \mathrm{O}\right) .{ }^{49} \mathrm{Zhang}$ et $a l .{ }^{49}$ has reported the same order of magnitude for the diffusivity of $\mathrm{H}_{2} \mathrm{O}$ in the center of the $\mathrm{MgSO}_{4} .7 \mathrm{H}_{2} \mathrm{O}$. Donkers et al. ${ }^{50}$ has measured the DC of water in epsomite using NMR. They reported the DC in range of $10^{-10}$ to $10^{-9} \mathrm{~m}^{2} \mathrm{~s}^{-1}$ in the temperature range of 293 to $413 \mathrm{~K}$. In the light of their experimental and simulation results of water diffusion in other heat storage material $\left(\mathrm{MgSO}_{4} \cdot 7 \mathrm{H}_{2} \mathrm{O}\right)$, we can conclude that the present ReaxFF-MD simulations could mimic the water transport in $\mathrm{MgCl}_{2}$ hydrates.

To investigate the effect of the temperature, the DC of $\mathrm{H}_{2} \mathrm{O}$ through 2D-periodic slabs of $\mathrm{MgCl}_{2} \cdot \mathrm{H}_{2} \mathrm{O}$ and $\mathrm{MgCl}_{2} \cdot 2 \mathrm{H}_{2} \mathrm{O}$ are obtained at various temperatures $(300,350,400,450$, and $500 \mathrm{~K})$. The rise in the temperature increased the thermal energy of $\mathrm{H}_{2} \mathrm{O}$ molecules and enhanced the water transport as shown in Table 2. The DC of $\mathrm{H}_{2} \mathrm{O}$ through 2D-periodic slabs at various temperatures follow the Arrhenius equation $\left(D(T)=D_{0} \times \mathrm{e}^{-[E / R T]}\right)$ with parameters given in Table 3. The activation energy and preexponential factor for $\mathrm{H}_{2} \mathrm{O}$ diffusion in $\mathrm{MgCl}_{2} \cdot \mathrm{H}_{2} \mathrm{O}$ is higher than $\mathrm{MgCl}_{2} \cdot 2 \mathrm{H}_{2} \mathrm{O}$, thus the net effect of the temperature on DC of $\mathrm{H}_{2} \mathrm{O}$ through $\mathrm{MgCl}_{2} \cdot \mathrm{H}_{2} \mathrm{O}$ is similar to $\mathrm{MgCl}_{2} \cdot 2 \mathrm{H}_{2} \mathrm{O}$. We have fitted the data on water-transport through the epsomite in the temperature range of 293 to $413 \mathrm{~K}^{50}$ The DC follows the Arrhenius equation. The activation energy and pre-exponential factor are $5.7 \times$ $10^{-4} \mathrm{~m}^{2} \mathrm{~s}^{-1}$ and $42.6 \mathrm{kcal} \mathrm{mol}^{-1}$. Thus, the strength of $\mathrm{Mg}-\mathrm{O}$

Table 3 Arrhenius parameters for $\mathrm{H}_{2} \mathrm{O}$ diffusion through 2D-periodic slabs of $\mathrm{MgCl}_{2} \cdot \mathrm{H}_{2} \mathrm{O}$ and $\mathrm{MgCl}_{2} \cdot 2 \mathrm{H}_{2} \mathrm{O}$

\begin{tabular}{lll}
\hline Material & $\begin{array}{l}\text { Pre exponential factor, } \\
D_{0} \mathrm{~m}^{2} \mathrm{~s}^{-1}\end{array}$ & $\begin{array}{l}\text { Activation energy, } \\
\mathrm{kJ} \mathrm{mol}^{-1}\end{array}$ \\
\hline $\mathrm{MgCl}_{2} \cdot \mathrm{H}_{2} \mathrm{O}$ & $7.72 \times 10^{-2}$ & 69.28 \\
$\mathrm{MgCl}_{2} \cdot 2 \mathrm{H}_{2} \mathrm{O}$ & $1.55 \times 10^{-5}$ & 32.22
\end{tabular}


bond in epsomite lies between the strength of $\mathrm{Mg}-\mathrm{O}$ bond present in $\mathrm{MgCl}_{2} \cdot \mathrm{H}_{2} \mathrm{O}$ and $\mathrm{MgCl}_{2} \cdot 2 \mathrm{H}_{2} \mathrm{O}$.

\section{Conclusions}

To gain more insight into the reaction kinetics of $\mathrm{MgCl}_{2}$ hydrates on molecular level, the development of a new reactive force field (ReaxFF) is desirable. This force field is trained against an extensive set of quantum mechanics data. ReaxFF is optimized against a training set consisting of bond dissociation curve, angle bending curve, enthalpy change in hydrolysis and dehydration reactions and equation of state (EOS). A singleparameter search algorithm in combination with a Metropolis Monte Carlo algorithm is used. The optimized force field is able to reproduce the energy terms along with the computationally challenging EOS of solid crystals. Bulk moduli of $\mathrm{MgCl}_{2} \cdot \mathrm{H}_{2} \mathrm{O}$ and $\mathrm{MgCl}_{2} \cdot 2 \mathrm{H}_{2} \mathrm{O}$ obtained from DFT and ReaxFF simulations are in close agreement ( $\sim 4 \%$ deviation). ReaxFF parameters from the present study represent various chemical bonds like $\mathrm{Mg}-\mathrm{O}, \mathrm{Mg}-\mathrm{Cl}$, and $\mathrm{O}-\mathrm{H}$ which are in agreement with the DFT and experimental structures.

Barriers of $19.55 \mathrm{kcal} \mathrm{mol}^{-1}$ and $29.61 \mathrm{kcal} \mathrm{mol}^{-1}$ for proton transfer in $\mathrm{MgCl}_{2} \cdot 2 \mathrm{H}_{2} \mathrm{O}$ and $\mathrm{MgCl}_{2} \cdot 2 \mathrm{H}_{2} \mathrm{O}$ surrounded by a neighbor $\mathrm{H}_{2} \mathrm{O}$ molecule are obtained from DFT calculations. The ReaxFF parameters are able to reproduce the barrier obtained from DFT calculations for the proton transfer in $\mathrm{MgCl}_{2} \cdot 2 \mathrm{H}_{2} \mathrm{O}\left(20.27 \mathrm{kcal} \mathrm{mol}^{-1}\right.$ ) and $\mathrm{MgCl}_{2} \cdot 2 \mathrm{H}_{2} \mathrm{O}$ surrounded by a neighbor $\mathrm{H}_{2} \mathrm{O}$ molecule $\left(26.54 \mathrm{kcal} \mathrm{mol}^{-1}\right)$. ReaxFF is also able to reproduce the reaction path for the proton transfer. This explains the lower hydrolysis in the higher hydrates (tetra and hexa) of $\mathrm{MgCl}_{2}$ as the neighboring $\mathrm{H}_{2} \mathrm{O}$ molecule in higher hydrates increases the barrier for proton transfer and inhibits the hydrolysis. The radial distribution functions for $\mathrm{Mg}-\mathrm{O}$, $\mathrm{O}-\mathrm{H}$, and $\mathrm{Mg}-\mathrm{Cl}$ pairs confirm that the optimized force field is able to capture the bonded and non-bonded interactions in the $\mathrm{MgCl}_{2}$ hydrates.

ReaxFF-MD simulations have been carried out on 2D periodic slabs of $\mathrm{MgCl}_{2} \cdot \mathrm{H}_{2} \mathrm{O}$ and $\mathrm{MgCl}_{2} \cdot 2 \mathrm{H}_{2} \mathrm{O}$ to investigate the dehydration and hydrolysis kinetics at various temperatures (300-500 K). The average number of $\mathrm{H}_{2} \mathrm{O}$ molecules escaping from the $\mathrm{MgCl}_{2} \cdot \mathrm{H}_{2} \mathrm{O}$ slab (after 1 nanosecond) increased from $21.38 \pm 4.45$ to $75.43 \pm 9.08$ in the temperature range of 300 to $500 \mathrm{~K}$. The dehydration rate increased 3.1 times in the same temperature range for $\mathrm{MgCl}_{2} \cdot \mathrm{H}_{2} \mathrm{O}$. The onset temperature of $\mathrm{HCl}$ formation in $\mathrm{MgCl}_{2} \cdot \mathrm{H}_{2} \mathrm{O}$ is observed to be $340 \mathrm{~K}$, which is in agreement with experiments. Increasing the temperature from 350 to $500 \mathrm{~K}$, we observed that the average number of $\mathrm{HCl}$ molecules escaping from the $\mathrm{MgCl}_{2} \cdot \mathrm{H}_{2} \mathrm{O}$ slab (after 1 nanosecond) increased from $12.29 \pm 4.51$ to $33.99 \pm 4.85$. The hydrolysis rate increased 2.8 times in the same temperature range for $\mathrm{MgCl}_{2} \cdot \mathrm{H}_{2} \mathrm{O}$. Increasing the temperatures from 300 to $450 \mathrm{~K}$, the average number of $\mathrm{H}_{2} \mathrm{O}$ molecules escaping from the $\mathrm{MgCl}_{2} \cdot 2 \mathrm{H}_{2} \mathrm{O}$ slab (after 1 nanosecond) increased from $54.93 \pm 6.76$ to $71.66 \pm 7.27$. Hydrolysis is not observed from the $\mathrm{MgCl}_{2} \cdot 2 \mathrm{H}_{2} \mathrm{O}$ slab in the temperature range of $300-500 \mathrm{~K}$.
The $\mathrm{H}_{2} \mathrm{O}$ transport through $\mathrm{MgCl}_{2} \cdot \mathrm{H}_{2} \mathrm{O}$ and $\mathrm{MgCl}_{2} \cdot 2 \mathrm{H}_{2} \mathrm{O}$ is investigated using ReaxFF-MD simulations. The diffusion coefficient (DC) of $\mathrm{H}_{2} \mathrm{O}$ through $\mathrm{MgCl}_{2}$ hydrates are reported from Green-Kubo method at various temperature ranging from 300-500 K. The DC of $\mathrm{H}_{2} \mathrm{O}$ in the present study is of the same order of magnitude as the DC of $\mathrm{H}_{2} \mathrm{O}$ in $\mathrm{MgSO}_{4} \cdot 7 \mathrm{H}_{2} \mathrm{O}$ obtained both from MD simulations ${ }^{49}$ and experiments. ${ }^{50}$ The DC increases with temperature and follows the Arrhenius law for $\mathrm{MgCl}_{2} \cdot \mathrm{H}_{2} \mathrm{O}$ and $\mathrm{MgCl}_{2} \cdot 2 \mathrm{H}_{2} \mathrm{O}$. The diffusivity of $\mathrm{H}_{2} \mathrm{O}$ through $\mathrm{MgCl}_{2} \cdot \mathrm{H}_{2} \mathrm{O}$ at $500 \mathrm{~K}$ increases 64 times compared with diffusivity at $300 \mathrm{~K}$. Similarly, the diffusivity of $\mathrm{H}_{2} \mathrm{O}$ through $\mathrm{MgCl}_{2} \cdot 2 \mathrm{H}_{2} \mathrm{O}$ at $500 \mathrm{~K}$ increased 57 times compared to the $300 \mathrm{~K}$. The diffusivity trend suggests that by increasing the temperature upto $500 \mathrm{~K}$, the $\mathrm{H}_{2} \mathrm{O}$ transport (mass diffusion) can be improved. These results demonstrate the ability of ReaxFF to explore the molecular reaction rate for dehydration/hydrolysis of $\mathrm{MgCl}_{2}$ hydrates along with the water transport in the operational range of seasonal heat storage systems.

\section{Acknowledgements}

This work is part of the Industrial Partnership Programme (IPP) 'Computational sciences for energy research' of the Foundation for Fundamental Research on Matter (FOM), which is part of the Netherlands Organisation for Scientific Research (NWO). This research programme is co-financed by Shell Global Solutions International B. V.

\section{References}

1 K. E. N’Tsoukpoe, H. Liu, N. Le Pierrès and L. Luo, Renewable Sustainable Energy Rev., 2009, 13, 2385-2396.

2 A. H. Abedin and M. A. Rosen, Open Renewable Energy J., 2011, 4, 42-46.

3 J. Xu, R. Wang and Y. Li, Sol. Energy, 2014, 103, 610-638.

4 D. Aydin, S. P. Casey and S. Riffat, Renewable Sustainable Energy Rev., 2015, 41, 356-367.

5 A. J. Carrillo, D. Sastre, D. P. Serrano, P. Pizarro and J. M. Coronado, Phys. Chem. Chem. Phys., 2016, 18, 8039-8048.

6 K. E. N'Tsoukpoe, T. Schmidt, H. U. Rammelberg, B. A. Watts and W. K. Ruck, Appl. Energy, 2014, 124, 1-16.

7 H. Zondag, V. Van Essen, L. Bleijendaal, B. Kikkert and M. Bakker, Proceedings IRES 2010 conference, Berlin, 2010.

8 B. Smeets, E. Iype, S. Nedea, H. Zondag and C. Rindt, J. Chem. Phys., 2013, 139, 124312.

9 A. El-Sebaii, S. Al-Amir, F. Al-Marzouki, A. S. Faidah, A. Al-Ghamdi and S. Al-Heniti, Energy Convers. Manage., 2009, 50, 3104-3111.

10 H. U. Rammelberg, T. Schmidt and W. Ruck, Energy Procedia, 2012, 30, 362-369.

11 A. El-Sebaii, S. Al-Heniti, F. Al-Agel, A. Al-Ghamdi and F. Al-Marzouki, Energy Convers. Manage., 2011, 52, 1771-1777.

12 P. F. Weck and E. Kim, J. Phys. Chem. C, 2014, 118, 4618-4625.

13 R. Pilar, L. Svoboda, P. Honcova and L. Oravova, Thermochim. Acta, 2012, 546, 81-86. 
14 G. J. Kipouros and D. R. Sadoway, J. Light Metals, 2001, 1, 111-117.

15 L. Guangming, M. Peihua, W. Zhiming, L. Mingzhen and C. Minxong, Thermochim. Acta, 2004, 412, 149-153.

16 W. Wang and S. Chen, Journal of Computational Science \& Engineering, 2011, 2, 79-84.

17 Q. Huang, G. Lu, J. Wang and J. Yu, J. Anal. Appl. Pyrolysis, 2011, 91, 159-164.

18 E. Iype, S. V. Nedea, C. C. M. Rindt, A. A. van Steenhoven, H. A. Zondag and A. P. J. Jansen, J. Phys. Chem. C, 2012, 116, 18584-18590.

19 S. Shoval, S. Yariv, Y. Kirsh and H. Peled, Thermochim. Acta, 1986, 109, 207-226.

20 Y. Kirsh, S. Yariv and S. Shoval, J. Therm. Anal., 1987, 32, 393-408.

21 A. K. Galwey and G. M. Laverty, Thermochim. Acta, 1989, 138, 115-127.

22 M. Dittner, J. Müller, H. M. Aktulga and B. Hartke, J. Comput. Chem., 2015, 36, 1550-1561.

23 C. Ferchaud, R. Scherpenborg, L. Scapino, J. Veldhuis, H. Zondag and R. D. Boer, Proceedings of the Advances in Thermal Energy Storage, Lleida, Spain, 2014.

24 S. Lan, H. Zondag, A. van Steenhoven and C. Rindt, J. Therm. Anal. Calorim., 2016, 1-10.

25 A. Pathak, S. Nedea, C. Rindt, D. Smeulders and H. Zondag, Proceedings NEGF 2015 conference, Eindhoven, 2015.

26 A. C. Van Duin, S. Dasgupta, F. Lorant and W. A. Goddard, J. Phys. Chem. A, 2001, 105, 9396-9409.

27 K. Chenoweth, A. C. v. Duin, P. Persson, M.-J. Cheng, J. Oxgaard and W. A. Goddard, III, J. Phys. Chem. C, 2008, 112, 14645-14654.

28 J. Ojwang, R. Van Santen, G. J. Kramer, A. C. van Duin and W. A. Goddard III, J. Chem. Phys., 2008, 128, 164714.

29 D. Raymand, A. C. van Duin, M. Baudin and K. Hermansson, Surf. Sci., 2008, 602, 1020-1031.

30 J. Ojwang, R. A. van Santen, G. J. Kramer, A. C. van Duin and W. A. Goddard III, J. Chem. Phys., 2009, 131, 044501.

31 K. Chenoweth, A. C. van Duin and W. A. Goddard, J. Phys. Chem. A, 2008, 112, 1040-1053.
32 A. C. van Duin, J. M. Baas and B. van de Graaf, J. Chem. Soc., Faraday Trans., 1994, 90, 2881-2895.

33 E. Iype, M. Hütter, A. Jansen, S. V. Nedea and C. Rindt, J. Comput. Chem., 2013, 34, 1143-1154.

34 G. Te Velde, F. M. Bickelhaupt, E. J. Baerends, C. Fonseca Guerra, S. J. van Gisbergen, J. G. Snijders and T. Ziegler, J. Comput. Chem., 2001, 22, 931-967.

35 A. D. Pathak, S. Nedea, H. Zondag, C. Rindt and D. Smeulders, Phys. Chem. Chem. Phys., 2016, 10059-10069.

36 G. Kresse and J. Furthmüller, Phys. Rev. B: Condens. Matter Mater. Phys., 1996, 54, 11169.

37 P. E. Blöchl, Phys. Rev. B: Condens. Matter Mater. Phys., 1994, 50, 17953.

38 J. P. Perdew, K. Burke and M. Ernzerhof, Phys. Rev. Lett., 1996, 77, 3865.

39 T. Liang, Y. K. Shin, Y.-T. Cheng, D. E. Yilmaz, K. G. Vishnu, O. Verners, C. Zou, S. R. Phillpot, S. B. Sinnott and A. C. van Duin, Annu. Rev. Mater. Res., 2013, 43, 109-129.

40 J. E. Mueller, A. C. T. van Duin and I. William A. Goddard, J. Phys. Chem. C, 2010, 114, 4939-4949.

41 G. Mazenko, J. Banavar and R. Gomer, Surf. Sci., 1981, 107, 459-468.

42 R. Wyckoff, Cryst. Struct., 1963, 1, 239-444.

43 K. Sugimoto, R. E. Dinnebier and J. C. Hanson, Acta Crystallogr., Sect. B: Struct. Sci., 2007, 63, 235-242.

44 J. A. Kaduk, Acta Crystallogr., Sect. B: Struct. Sci., 2002, 58, 370-379.

45 http://www.crystallography.net/.

46 A. L. Kaledin, A. C. van Duin, C. L. Hill and D. G. Musaev, J. Phys. Chem. A, 2013, 117, 6967-6974.

47 C. Ferchaud, PhD thesis, Eindhoven University of Technology, 2016.

48 E. Chiavazzo, M. Fasano, P. Asinari and P. Decuzzi, Nat. Commun., 2014, 5.

49 H. Zhang, E. Iype, S. V. Nedea and C. C. Rindt, Mol. Simul., 2014, 40, 1157-1166.

50 P. A. J. Donkers, S. Beckert, L. Pel, F. Stallmach, M. Steiger and O. C. G. Adan, J. Phys. Chem. C, 2015, 119, 28711-28720. 